\title{
INVESTIGATION OF OAK TREE DECLINE IN THE AUCKLAND REGION
}

\author{
M. BRAITHWAITE ${ }^{1}$, C. INGLIS ${ }^{2}$, M.A. DICK ${ }^{3}$, T.D. RAMSFIELD ${ }^{3}$, \\ N.W. WAIPARA ${ }^{4}$, R.E. BEEVER ${ }^{4}$, J.M. PAY ${ }^{1}$ and C.F. HILL ${ }^{2}$ \\ ${ }^{1}$ Investigation and Diagnostic Centre, Biosecurity New Zealand, \\ MAF, PO Box 24, Lincoln 8152, New Zealand \\ ${ }^{2}$ Investigation and Diagnostic Centre, Biosecurity New Zealand, \\ MAF, PO Box 2095, Auckland 1140, New Zealand \\ ${ }^{3}$ Ensis, Private Bag 3020, Rotorua, New Zealand \\ ${ }^{4}$ Landcare Research, Private Bag 92170, Auckland, New Zealand
}

Corresponding author: Mark.Braithwaite@maf.govt.nz.

\begin{abstract}
Concern about the poor health of oak trees in Auckland was raised in 2001. An intensive investigation of oak trees showing symptoms of decline (twig and branch dieback, epicormic growth, trunk cankers, bark loss and tree death) was conducted in the Auckland area during 2006. Disease symptoms on trees at 13 sites were documented and samples of leaves, stems, trunks, roots and soil collected. Soil samples were tested for the presence of soil-borne fungi using baiting techniques. Fungi and bacteria from plant tissues and soil were identified using either morphological characteristics, biochemical testing or molecular techniques. The investigation resulted in a range of fungi and bacteria being identified. One fungus new to New Zealand was detected and several new host associations observed. No particular organism was implicated as the cause of the oak decline, but several fungi and bacteria were likely contributors to the tree decline and death in Auckland.
\end{abstract}

\section{INTRODUCTION}

A general decline of oak trees, in particular Quercus robur and the hybrid $Q$. robur $\times$ Q. canariensis, has been observed in greater Auckland, including North Shore City. The oak trees at One Tree Hill Domain were of particular concern as a significant number of mature and semi-mature trees were affected (Fig. 1). Since 2002, at this site a total of 108 out of 149 trees that were in reasonable health have either died or suffered a marked deterioration of their green crowns, sometimes within one growing season (G. Collett, pers. comm.). A similar rate of attrition has been observed in other Auckland areas, including parks, church grounds, schools, a technical institute and private property. Observed symptoms included twig and branch dieback, epicormic growth, trunk cankers (some exuding sap), bark loss and tree death (Collett 2006).

The aim of the present investigation was to examine trees for possible causes of decline and death. The presence of soil and root, trunk, branch and foliar pathogens were tested for, including fungi, bacteria and nematodes. In addition, soil and foliage were tested for macro- and micro-nutrients, and growth rings of dead or dying trees were examined. This paper presents the results of this investigation and discusses the possible implications of the organisms found in relation to the observed tree decline.

\section{MATERIALS AND METHODS}

Thirteen sites in the Auckland metropolitan area (Table 1) with mature and semimature Quercus robur and $Q$. robur $\times Q$. canariensis trees showing symptoms of decline, were surveyed by Investigation and Diagnostic Centre, Ensis and Landcare Research 


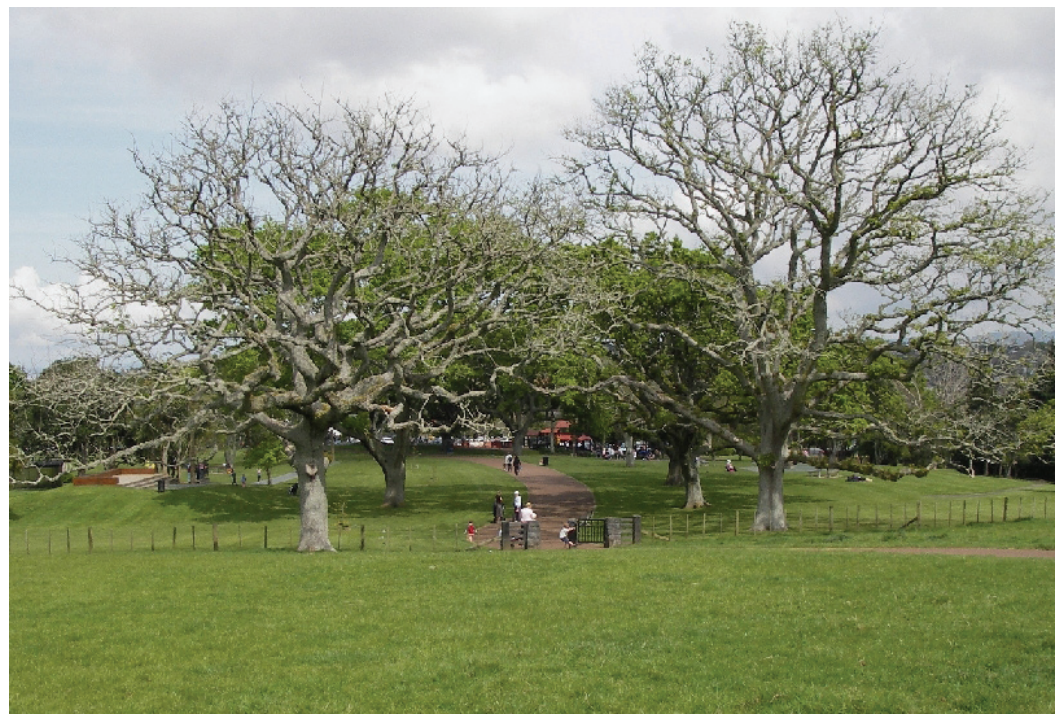

FIGURE 1: Oak trees in One Tree Hill Domain showing decline symptoms.

staff between 2002 and 2006. Plants were examined for disease symptoms and samples collected for laboratory analyses. Samples consisted of leaves, twigs, stems, wood, roots and soil (taken from between the tree drip-line and trunk to a depth of $20 \mathrm{~cm}$ ). All samples were each given a unique identification number. All sampling equipment was thoroughly cleaned between sites to prevent potential spread of disease.

The determination of fungi and bacteria present was made indirectly after isolation to agar culture, except for the powdery mildew (Microsphaera alphitoides) and frosty mildew (Microstroma album), which were observed in the living state on affected leaves. Fungi were cultured from excised, diseased tissues that had been surface sterilised in either sodium hypochlorite or hydrogen peroxide and then washed in sterile water. These small pieces of tissue, taken from the boundary between diseased and healthy tissues, were plated directly onto a general growth medium. The Petri dishes were incubated at $20-22^{\circ} \mathrm{C}$ for up to 10 days or until sufficient growth or sporulation of isolated microorganisms enabled identification using morphological characteristics. Samples of fine root tissue were directly plated to Phytophthora-selective media (Jung et al. 1999). Soil samples were baited with cedar needles (using a modification of the Phytophthora bioassay technique developed by Dance et al. (1975)), rhododendron leaves (Werres et al. 1997), lupin seedlings (Erwin \& Ribero 1996), Granny Smith apples (Brasier \& Strouts 1976) and oak leaves. Baits were then placed on a general growth medium or a Phytophthora-selective medium (Erwin \& Ribero 1996) in Petri dishes, which were incubated and examined as described above.

One objective of this investigation was to clarify whether Ceratocystis fagacearum, the agent responsible for the devastating oak wilt in North America, or Phytophthora ramorum, the cause of the disease known as sudden oak death overseas, were implicated as agents causing oak decline in Auckland.

For culture of bacteria, small pieces of tissue showing infection were excised aseptically using a scalpel and macerated in $100 \mu \mathrm{l}$ of sterile distilled water. The subsequent bacterial suspension was streaked onto King's B agar plates and incubated at $28^{\circ} \mathrm{C} \pm 1^{\circ} \mathrm{C}$ for 24-36 hours. Morphologically different colonies were purified on King's B agar or 
Biolog Universal Growth Agar (BUG ${ }^{\mathrm{TM}}$ Agar, Biolog Inc., CA, USA) plates. Pure cultures were used for biochemical testing (Gram stain, oxidase production, fluorescence and carbon source utilisation patterns using GN2 Microplates TM, Biolog Inc., CA, USA).

Where possible, identifications of fungi and bacteria were carried out to species level. Where necessary, identification was achieved by generating sequences of their ITS region for fungi (White et al. 1990) or 16S region for bacteria (Godfrey et al. 2001) and comparing these to sequences deposited in the GenBank database. Phytophthora spp. were also identified by sequencing the ITS region (Cooke et al. 2000). All new pest associations were entered into MAF's Plant Pest Information Network database (PPIN). All organisms new to New Zealand were validated by a second practising plant pathologist and fungi new to New Zealand were investigated further by MAF Biosecurity New Zealand.

Soil samples were examined for nematodes by first thoroughly mixing a 250-300 ml sub-sample then extracting nematodes using a modified Whitehead tray (Whitehead \& Hemming 1965) for 48-72 hours. The elutriate was then condensed to a $1 \mathrm{ml}$ sample in a Baermann funnel type apparatus (Southey 1986). While samples were live and fresh a 5\% subsample was heat killed and immediately microscopically examined under phase contrast at $\times 10$ or $\times 400$ magnification. Initial identifications were made for later reference. The remaining $95 \%$ of the sample was heated to $60^{\circ} \mathrm{C}$ for $1 \mathrm{~min}$ and added to an equal volume of $6 \%$ formalin. After a period of fixing in formalin of not less than 4 weeks the samples were examined under $\times 50$ magnification, and plant parasitic nematodes were hand picked into cold lactophenol. The original "fresh" observations were used either to ensure nematodes that could not be confidently identified in initial water mounts were included or to ignore those that had been identified already. The lactophenol was then heated and cooled, and then the nematodes were transferred to permanent mounts of glycerol and microscopically examined under interference contrast at $\times 1000$ magnification.

Three diseased trees were chosen for macro and micro nutrient analyses, two from One Tree Hill Domain and one from Auckland Domain. The soil type from both sites is recent volcanic ash. One Tree Hill Domain carries both sheep and cattle at a low productivity level. Foliage and soil samples were sent to the Forest Nutrition Laboratory, Veritec, at Scion, Rotorua for analyses.

Growth rings were measured from discs cut at stump height from nine dead or near dead trees in One Tree Hill Domain.

\section{RESULTS AND DISCUSSION}

Twenty-nine fungi and four bacteria were associated with various root, trunk, stem and foliage symptoms on the declining oak trees (Table 1). These included known primary and secondary pathogens. A range of saprophytic organisms was also obtained (mostly not presented here). Neither Ceratocystis fagacearum nor Phytophthora ramorum were detected during this investigation. Although considerable effort was made to isolate Phytophthora spp., they were rarely found. However, the related root pathogens Pythium spp. were frequently recovered using the baiting methods. Pythium spp. are associated with minor root rots and lesions, particularly of the fine roots of many plant hosts (Robertson 1980), often referred to as 'root nibbling'. Further work to identify these fungi to species level is in progress.

A number of the fungi that were isolated from the leaves and stems of oak trees (Apiognomonia quercina, Microsphaera alphitoides, Tubakia dryina, Colletotrichum acutatum, Phomopsis sp. and Botryosphaeria spp.) were considered capable of causing premature leaf fall and twig dieback, potentially contributing to oak decline and death as observed in Auckland.

The powdery mildew fungus $M$. alphitoides has been identified regularly on species of Quercus in and around Auckland since 1961 (Ensis Forest Health Database, Landcare Research Database). Powdery mildew is favoured by warm conditions, high humidity and low light, and young, succulent foliage is particularly susceptible to infection. 
There have been serious powdery mildew outbreaks in Auckland in the spring months of some recent years. City arborists have been so concerned at the repeated defoliation caused by powdery mildew that a fungicide spray programme using aerial applications of bicarbonate of soda was undertaken in 2004, 2005 and 2006 in an attempt to control the disease (B. Edwards, pers. comm.).

The fungus A. quercina (anamorph Discula quercina), which causes oak anthracnose, was recorded for the first time in New Zealand. There are inconsistencies in the naming of this organism in the literature, in particular its synonymy with A. errabunda (beech anthracnose). However, it is agreed that A. quercina is a specific pathogen of oak (Anon. 2004). This fungus has been associated with declining oaks in Europe (Ragazzi et al. 1999). The pathogen can infect the leaves and stems of oak and be associated with defoliation, twig dieback and a thinning of tree canopies (Anon. 2004). Repeated infections over several years have been implicated in tree death. Apiognomonia quercina was identified at four of the sites examined.

Tubakia dryina, which causes Tubakia leaf spot, was one of the most consistently cultured fungi from the oak leaves and stems, being present at nine of the 13 sites sampled. This fungus may be playing a significant role in the oak tree decline (Table 1) as it was observed reinfecting newly flushing leaves following the collapse of earlier spring growth. It has also been reported as causing premature leaf fall and stem cankers on oak in the USA (Pearce \& Williams-Woodward 2005), and is associated with declining Q. robur trees in Italy (Gennaro et al. 2003).

The fungi $C$. acutatum, Phomopsis sp. and Botryosphaeria parva were prevalent at many of the sites surveyed (Table 1). Although not considered primary or recognised pathogens of oak, they are likely contributors to the dieback symptoms observed, especially on twigs and small branches.

Phytophthora gonapodyides was detected from soil around a single tree showing dieback and root rot. There had been considerable root disturbance and movement of soil around the base of this tree, which was the likely cause of infection by this fungus.

The four bacteria cultured (Table 1) are likely to be secondary or saprophytic organisms and all have been associated with the condition known overseas as bacterial wet wood or slime flux in trees. Bacterial wet wood tends to occur on mature trees and is not usually a problem on otherwise healthy trees (Jones \& Grand 2000). In severe cases, leaves of affected trees may wilt and branch dieback can occur (Pearce \& Williams-Woodward 2005). Wet wood develops following a build-up of bacterial populations in the wood, which cause fermentation and carbon dioxide gas formation and, in turn a weeping of sap. Two of the bacteria (Erwinia billingiae and Pantoea cedenensis) have not officially been recorded in New Zealand. However, these two bacteria, previously classified as non-pigmented strains of $E$. herbicola $(=P$. agglomerans $)$ associated with trees, have been subjected to molecular studies and reclassified (Mergaert et al. 1999). These changes make previous New Zealand records difficult to interpret.

Although insect pests were not a focus during this investigation, the examination of historical records of insects in the Ensis Forest Health Database showed that the most frequently occurring insect damage on oaks was caused by the leaf miner, Phyllonorycter messaniella. The effects of this insect on general tree health are considered to be minor, although leaf miners may open up infection courts through the leaf damage they cause. The polyphagus native lemon tree borer, Oemona hirta, was the second most frequently recorded insect. This insect can cause significant die-back in tree crowns and severe damage to the stems of young saplings.

Golden oak scale, Asterodiaspis variolosa, appears to be rare in Auckland, with only three scale insects found during the 2006 investigation. When this pest first became established in New Zealand in the early 1920s it was reported as killing Q. robur (Miller 1925). Biological control proved to be very effective with the introduction of the parasitic wasp, Habrolepis dalmanni (Miller 1971). Golden oak scale is currently common in Timaru with no apparent effect on $Q$. robur. Habrolepis dalmanni is also present in large numbers. Golden oak scale is associated with oak anthracnose disease in the Northeast of the United States of America (Sinclair \& Lyon 2005). 
Five nematodes, Longidorus elongatus, Helicotylenchus pseudorobustus, Meloidogyne fallax, Paratylenchus nanus and Macroposthonia sp., were identified from soil samples taken from One Tree Hill Domain during the 2006 investigation. All are considered to be widespread and not agents of disease.

Growth ring development over the total life of the sampled trees, which were planted in the early 1900s, indicated that annual growth was normal right up to tree death in all cases, emphasising the sudden nature of this decline (illustrated for one tree in Fig. 2).

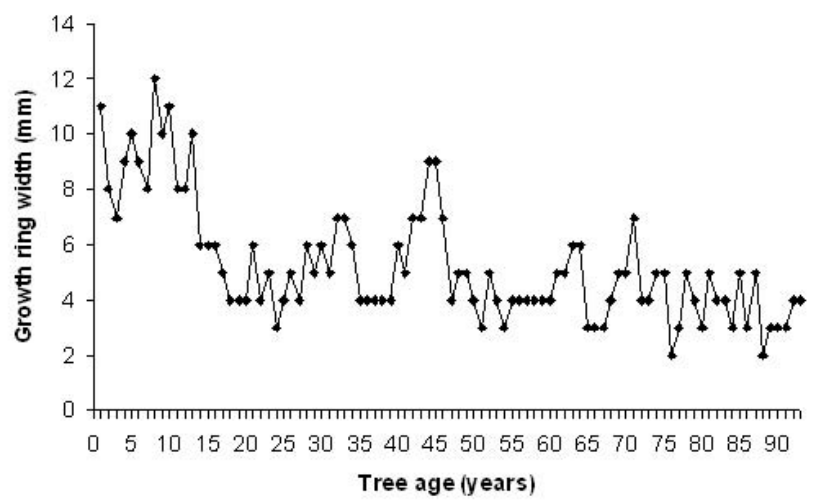

\section{FIGURE 2: Growth ring widths for an oak tree (\#D11) from One Tree Hill Domain.}

It is concluded that no single pathogen readily accounts for the decline of the oak trees in the Auckland region. However, some significant primary and secondary pathogens that are capable of causing severe defoliation, dieback and thinning of tree canopies were found infecting the trees in which decline symptoms were observed. Repeated infection over several years may be a major contributing factor to this decline. Similar conclusions have been reached by researchers investigating oak decline in other parts of the world. The role of insects is probably minor compared to pathogens, although the lemon tree borer is widespread and likely to be adding significantly to branch tip dieback on infested trees. The decline is apparently restricted to $Q$. robur and this raises questions about the suitability of this species as a long-lasting specimen tree for the Auckland region.

\section{ACKNOWLEDGEMENTS}

We thank Auckland City Council arborists Simon Cook and Bruce Edwards; consultant arborist Gerald Collett (Treecare Services Ltd); Mike Wilcox (President of the Auckland Botanical Society); Chris Scott and John Goodenough (Biosecurity Advisors, Target Pest); Lindsay Bulman, (plant pathologist, Ensis) for providing historical records of pests and diseases of oak species in Auckland; Michael Ayrton (Park Director, Cornwall Park Trust Board); Karen Knight (previously Nematologist, Biosecurity New Zealand for nematode identifications); Stephanie Parkes and Sarah Tsai (technical assistance at Landcare Research); Sara Glasson (technical assistance at Biosecurity New Zealand); and Miranda Bennett, Don Austin and Mike Harie (Auckland Regional Council) for undertaking the growth ring counts. 


\section{REFERENCES}

Anon. 2004. Apiognomonia errabunda data sheet. Crop Protection Compendium, CABI International. Available online at: http://www.cabi.org/compendia/cpc (last accessed 30 April 2007).

Brasier CM, Strouts RG 1976. Taxonomy of Phytophthora on trees in Britain I. Phytophthora root rot and bleeding canker of horse chestnut (Aesculus hippocastanum L.). European Journal of Forest Pathology 6: 129-136.

Collett G 2006. One Tree Hill Domain - Maungakiekie - Oak Avenues. Review of Dead and Dying Oaks. Arborist report for Auckland City Council Parks and Streetscape Services, Treecare Services Ltd, Auckland. 31 pp.

Cooke DEL, Drenth A, Duncan JM, Wagels G, Brasier CM 2000. A molecular phylogeny of Phytophthora and related Oomycetes. Fungal Genetics and Biology 30: 17-32.

Dance MH, Newhook FJ, Cole J 1975. Bioassay of Phytophthora spp. in soil. Plant Disease Reporter 69: 523-527.

Erwin DC, Ribero OK 1996. Phytophthora Diseases Worldwide. APS Press, St Paul, USA. p. 39.

Gennaro M, Gonthier P, Nicolotti G 2003. Fungal endophytic communities in healthy and declining Quercus robur and Q. cerris trees in northern Italy. Journal of Phytopathology 151: 529-534.

Godfrey SAC, Harrow SA, Marshall JW, Klena JD 2001. Characterisation by 16S rRNA sequence analysis of Pseudomonads causing blotch disease of cultivated Agaricus bisporus. Applied and Environmental Microbiology 67: 4316-4323.

Jones RK, Grand LF 2000. Slime Flux/Wet Wood. North Carolina State University, Ornamental Disease Note No. 8. 1 p. Available online at: http://www.ces.ncsu. edu/depts/pp/notes/oldnotes/od8.htm (last accessed 30 April 2007).

Jung T, Cooke DEL, Blaschke H, Duncan JM, Oßwald W 1999. Phytophthora quercina sp. nov., causing root rot of European oaks. Mycological Research 103: 785-798.

Mergaert J, Hauben L, Cnockaert MC, Swings J 1999. Reclassification of non-pigmented Erwinia herbicola strains from trees as Erwinia billingiae sp. nov. International Journal of Systemic Bacteriology 49: 377-383.

Miller D 1925. Forest and Timber Insects in New Zealand. New Zealand State Forest Service, Bulletin No 2. WAG Skinner, Government Printer, Wellington.76 pp.

Miller D 1971. Common Insects of New Zealand. AH and AW Reed, Wellington. 178 pp.

Pearce M, Williams-Woodward J 2005. Key to diseases of oaks in the landscape. The University of Georgia Co-operative Extension Bulletin 1287, 16 pp. Available online at: http://pubs.caes.uga.edu/caespubs/pubs/PDF/B1286.pdf (last accessed 30 April 2007).

Ragazzi A, Moricca S, Capretti P, Dellavalle I 1999. Endophytic presence of Discula quercina on declining Quercus cerris. Journal of Phytopathology 147: 437-440.

Robertson GI 1980. The genus Pythium in New Zealand. New Zealand Journal of Botany 18: 73-102.

Sinclair, WA, Lyon HH 2005. Oak Anthracnose. Diseases of Trees and Shrubs, Second Edition. Cornell University Press, New York. p. 100.

Southey JF 1986. Principles of sampling for nematodes. In: Southey JF ed. Laboratory methods for work with plant and soil nematodes. Reference Book 402, ADAS Ministry of Agriculture, Fisheries and Food, HMSO, London, UK.

Werres S, Hahn R, Themann K 1997. Application of different techniques to detect Phytophthora spp. in roots of commercially produced Chamaecyparis lawsoniana. Zeitschrift fur Pflanzenkrankheiten und Pflanzenschutz 104: 474-482.

White TJ, Bruns T, Lee S, Taylor J 1990. Amplifiation and direct sequencing of fungal ribosomal RNA genes for phylogenetics. In: Innis MA, Gelfand DH, Sninsky JJ, White TJ ed. Methods in Plant Molecular Biology and Biotechnology. Academic Press, San Diego. Pp. 315-332.

Whitehead AG, Hemming JR 1965. A comparison of some quantitative methods of extracting some small vermiform nematodes from soil. Annals of Applied Biology 